\title{
The fruitful death of modal collapse arguments
}

\author{
Joseph C. Schmid ${ }^{1}$
}

Received: 10 June 2021 / Accepted: 4 July 2021

(c) Springer Nature B.V. 2021

\begin{abstract}
Modal collapse arguments are all the rage in certain philosophical circles as of late. The arguments purport to show that classical theism entails the absurdly fatalistic conclusion that everything exists necessarily. My first aim in this paper is bold: to put an end to action-based modal collapse arguments against classical theism. To accomplish this, I first articulate the 'Simple Modal Collapse Argument' and then characterize and defend Tomaszewski's criticism thereof. Second, I critically examine Mullins' new modal collapse argument formulated in response to the aforementioned criticism. I argue that Mullins' new argument does not succeed. Third, I critically examine a powers-based modal collapse argument against classical theism that has received much less attention in the literature. Fourth, I show why God's being purely actual, as well God's being identical to each of God's acts, simply cannot entail modal collapse given indeterministic causation. This, I take it, signals the death of modal collapse arguments. But not all hope is lost for proponents of modal collapse arguments - for the death is a fruitful one insofar as it paves the way for new inquiry into at least two new potential problems for classical theism. Showing this is my paper's second aim.
\end{abstract}

Keywords Modal collapse - Divine simplicity · Classical theism · Divine action · Models of god

\section{Introduction}

A core component of classical theism-or, more accurately, versions of classical theism like those of Aquinas, Anselm, Augustine, and the gang-is the Doctrine of Divine Simplicity (DDS). According to DDS, God is completely devoid of physical, metaphysical, and logical parts. He is identical to his essence, existence, attributes, action, power, and so on. On DDS, each of the following-when distinct in something - are component parts: essence and existence, subject and accidents,

Joseph C. Schmid

schmi215@purdue.edu

1 Purdue University, West Lafayette, IN, USA 
individual and its essence, individual and its properties, act and potency, and agent and the agent's actions. ${ }^{1}$ As Katherin Rogers puts it, DDS "denies that God has any properties at all. God is an act... an eternal, immutable, absolutely simple act. ... God simply is an act, and all the words we use to describe God refer to this act" (1996, p. 166).

In the context of DDS, $x$ is part of $S$ just in case (i) $x$ is some positive ontological item intrinsic to $\mathrm{S}$ and (ii) $\mathrm{x}$ is not identical to $\mathrm{S} .{ }^{2}$ More simply (and applied to God), "[a]nything intrinsic to God is identical to God" (Fakhri 2021). This understanding of parts accords with how DDS is traditionally articulated. As Augustine famously put it, God is what he has (Augustine 1887, XI, 10). Similarly with Anselm: "you [God] are whatever you are... you are the very life by which you live, the wisdom by which you are wise, the very goodness by which you are good" (Anselm 2001, ch. 12). Vallicella (2019) similarly follows suit: "God is ontologically simple... there is nothing intrinsic to God that is distinct from God." Other scholars are similarly explicit about this conception of parthood in relation to DDS. ${ }^{3}$ In motto form: whatever is in God is God.

But if everything in God is God, such that all of God's acts are numerically identical to one another and to God himself, a problem seems to arise. For one of God's acts is the act of creation, which (according to classical theism) extends to any positive ontological item distinct from God. ${ }^{4}$ But in that case, God is numerically identical to God's act of creation. And from this it seems to follow that-since God exists of metaphysical necessity-God's act of creation likewise exists of metaphysical necessity. And if God's act of creation exists of metaphysical necessity, then it would seem to follow that everything is metaphysically necessary. It would seem that contingency is vanquished from the world. All modal categories collapse into a single category: metaphysical necessity. ${ }^{5}$

\footnotetext{
1 Hughes (2018, p. 2), Bergmann and Brower (2006, pp. 359-360), Dolezal (2017, pp. 41-42), Duby (2016, p. 2), Mullins (2021).

2 Two notes. First, a positive ontological item is anything that exists (has being or reality). Second, what intrinsicality consists in is a matter of debate. We can make do with an intuitive understanding thereof, since nothing in my paper hangs on a precise and formalized account. I follow David Lewis's classic articulation: "We distinguish intrinsic properties, which things have in virtue of the way they themselves are, from extrinsic properties, which they have in virtue of their relations or lack of relations to other things" (Lewis, 1986, p. 61). Intrinsic properties (else: predicates), then, characterize something as it is in itself, without reference to things wholly apart from or outside of or disjoint from the thing in question. By contrast, extrinsic properties (else: predicates) characterize something as it is in relation or connection with something wholly apart from or outside it (or as it fails to be so related). For an overview of debates concerning intrinsicality and extrinsicality, see Marshall and Weatherson (2018).

3 This understanding of parts in connection with DDS is explicit in Spencer (2017, p. 123), Brower (2009, p. 105), Stump (2013, p. 33), Grant (2012, p. 254), Schmid and Mullins (2021), Leftow (2015, p. 48), Sijuwade (2021), and Dolezal (2011, p. xvii), inter alia.

4 Rogers (1996, p. 167), Bergmann and Brower (2006, p. 361), Grant (2019, ch. 1).

5 First, a note. I follow the standard usages of possibility, contingency, and necessity in modal collapse debates. I shall also use possible worlds as a semantic device without ontological import. As I use it, a possible world is just a complete, maximal, or total way reality could be. Second, some definitions. Something exists (obtains, is true) contingently if and only if it exists (obtains, is true) in some possible worlds but not others. In other words, it is possibly within reality, but it is also possibly absent from reality. It can fail to exist (obtain, be true). By contrast, something exists (obtains, is true) necessarily if and only if it exists (obtains, is true) in all possible worlds. It must be in reality; it cannot fail to exist.
} 
This problem is the (in)famous modal collapse objection to classical theism. Ryan Mullins aptly summarizes the argument as follows:

Does divine simplicity entail a modal collapse? Yes. ... On divine simplicity God's essence is identical to His existence. Also, God's one simple act is identical to His essence/existence. God's act of creation is identical to this one simple act, and so identical to God's essence/existence. God exists of absolute necessity. So His act of creation is of absolute necessity since it is identical to His essence/existence. (Mullins, 2016, p. 138)

Similar arguments are found in Mullins (2013), Leftow (2015, p. 48), and Moreland and Craig (2003, p. 525). The argument in each of these cases reasons from the necessity of God's act of willing creation to the necessity of everything in creation. (Leftow, though, does not endorse the argument.)

This objection to divine simplicity is all the rage as of late in some philosophy of religion circles. According to Tomaszewski (2019), the modal collapse argument rests on an invalid substitution of a non-rigid singular term ('God's act of creation') for a rigid proper name ('God') in a referentially opaque or intensional context. Waldrop (Forthcoming) responds to Tomaszewski by offering a number of valid reformulations of the argument that rigidify the singular term 'God's act of creation' through the addition of an essentiality thesis (E), according to which "necessarily, something is a divine creative act only if it is essentially the unique divine creative act" (Waldrop, Forthcoming). Mullins (2021) also responds to Tomaszewski by formulating the argument in a way that, by Mullins' lights, preserves validity while delivering modal collapse from the core commitments of DDS.

Nemes (2020) argues that the modal collapse argument presupposes (what he terms) the difference principle, according to which any difference in effect (across worlds) presupposes a difference in cause (across worlds). But for Nemes, a classical theist is well within their epistemic rights in simply rejecting this principle. Fakhri (2021) develops a similar line of thought but uses it to defend (a version of) the modal collapse argument. According to Fakhri, non-classical theistic models of God enjoy an explanatory advantage over classical theism. This is because non-classical theistic models can preserve the principle that differences in effects require differences in the cause by holding that cross-world differences in creation are caused by numerically distinct acts of divine will. And these differences in God's will across worlds are non-causally explained by different reasons across worlds. Neither a multiplicity of reasons nor numerically distinct acts of will are open to the classical theist (as they introduce multiplicity into the Godhead, contra DDS). ${ }^{6}$ Thus,

\footnotetext{
6 Assuming, of course, that reasons are or would be mental items of some kind and, hence, positive ontological items intrinsic to but distinct from God.
} 
non-classical theistic models are explanatorily superior to classical theistic ones-or so Fakhri argues. ${ }^{7}$

My general aim in this paper is to advance this blossoming debate on the modal collapse argument. First, I articulate and assess what I call the 'Simple Modal Collapse Argument' (\$2). Second, I critically examine Mullins’ (2021) new modal collapse argument (\$3). Third, I critically examine a powers-based modal collapse argument against classical theism that has received much less attention in the literature (§4). Fourth, I show why God's being purely actual, as well God's being identical to each of God's acts, simply cannot entail modal collapse given indeterministic causation (\$5). This death of modal collapse arguments, though, is a fruitful one insofar as it paves the way for inquiry into new potential problems for classical theism. I sketch and motivate, but do not defend, these new potential problems in ( $\$ 6)$. The hope is that future work in the debate over models of God will move beyond modal collapse arguments and focus on (inter alia) these new problems that result from the death of modal collapse arguments.

Without further ado, let's proceed to $\$ 2$.

\section{Simple modal collapse argument}

The Simple Modal Collapse Argument (SMCA) reasons from the identity of God and each of God's acts (and, in particular, God's creative act) to the necessity of creation. ('Creation' includes everything in creation.) There are two ways to motivate the inference from the identity of God and God's acts to the necessity of creation: (i) from the intersubstitutability of identicals or co-referential terms and (ii) from Leibniz's Law. Let's consider each in turn.

\section{Intersubstitutability of identicals}

The SMCA based on the intersubstitutability of identicals can be formulated as follows (Tomaszewski, 2019, p. 277):

1. Necessarily, God exists.

2. God is identical to God's act of creation.

3. Necessarily, God's act of creation exists.

The inference from (1) and (2) to (3), according to the intersubstitutability of identicals version of the SMCA, relies on the principle that if 'God' refers to one and the same thing as 'God's act of creation' — as captured in (2) - then the latter can be

\footnotetext{
7 Modal collapse arguments have been developed that also focus on God's knowledge. For treatments, see Schmid and Mullins (2021), Grant (2012), Grant and Spencer (2015), and Moreland and Craig (2003, p. 525). I will only be focusing on modal collapse arguments based either on God's pure actuality or else God's identity with God's acts. Thus, when I say 'the modal collapse argument', I only mean this latter type of modal collapse argument.
} 
substituted for the former into premise (1) without (potentially) changing the truth value of the sentence as a whole.

The problem, though — as pointed out by Tomaszewski (2019) — is that the linguistic context at hand is precisely one in which the intersubstitutability of co-referring expressions salva veritate fails. More to the point, the linguistic context of (1) is an intensional context by dint of being a modal context. Intensional contexts are ones wherein one cannot intersubstitute co-referring expressions without potentially changing the truth value of the relevant sentence. The problem with the above argument, then, is that it illicitly substitutes expressions within an intensional or referentially opaque context.

This version of the SMCA argument, then, is no good. It mistakenly assumes, based on an identity claim flanked by non-rigid and rigid designators, that a substitution of such designators in a modal (and, hence, intensional) context will preserve truth. A valid argument only arises if we rigidify (i.e., make rigid) the description 'the divine creative act' or the singular term 'God's creative act' in some way. But at least on the ways canvassed in Tomaszewski (2019), such ways either render the argument unsound or question-begging (since no classical theist would grant that 'the divine creative act' rigidly designates God or that God necessarily satisfies the description 'the divine creative act', for that just means that God necessarily creates).

But the intersubstitutability version of SMCA won't go down without a fight. Consider God's actual act of creation. ${ }^{8}$ On DDS, God is numerically identical to God's actual act of creation. And unlike premise (2) in the original argument, the expression 'God's actual act of creation' picks out the very same act in all possible worlds. The expression, in other words, rigidly designates God. ${ }^{9}$ With this in hand, we can modify premises (2) and (3) as follows (cf. Waldrop, Forthcoming):

1. Necessarily, God exists.

2*. God is identical to God's actual act of creation.

$3^{*}$. Necessarily, God's actual act of creation exists.

This argument is, indeed, valid. Nor is there any untoward question-begging hereon DDS, there can be no distinction between God and God's actual creative act, for that would introduce a composition of agent and action in God. The argument, then-by the classical theist's own lights-is sound. The question is whether $\left(3^{*}\right)$ entails modal collapse.

Here's the crux: if God's creative act is deterministic-i.e., if God's creative act necessitates its effect-then modal collapse straightforwardly ensues in conjunction with $\left(3^{*}\right)$. For God's actual creative act brings about everything numerically distinct from God. Hence, given the necessity of said act and the fact that causal acts

\footnotetext{
${ }^{8}$ I am thankful to an anonymous referee for bringing this line of response to my attention. See Waldrop (Forthcoming) for a further discussion of ways to rigidify 'God's act of creation', including various additions of actuality operators and an essentiality thesis.

9 Definite descriptions and singular terms, when indexed to a designated world by an actuality operator, become rigid. Cf. Waldrop (Forthcoming) and Kaplan (1979).
} 
necessitate what they bring about, a simple application of the distribution axiom entails that everything numerically distinct from God is likewise necessary. The argument:

4. Necessarily, God's actual act of creation exists.

5. Necessarily, if God's actual act of creation exists, the actual creation exists. ${ }^{10}$

6. Necessarily, the actual creation exists.

Premise (4) is identical to ( $\left.3^{*}\right)$, which was established above. Premise (5) asserts that the causal link between God's actual creative act and the actual world is deterministic: God's actual act of creation (i.e., God's actual willing that the actual creation exist) necessitates or determines the existence of the actual creation. This necessitation or determinism is represented by the necessary conditional statement in (5). ${ }^{11}$ The conclusion, (6), follows from (4) and (5) by the distribution axiom. And (6) clearly entails modal collapse.

The only way for the classical theist to avert modal collapse, then, is to deny premise (5). Thus, the classical theist can only avert modal collapse if God's act merely indeterministically produces its effects. Across all possible worlds, God's one, simple act remains utterly the same, whereas the various created outcomes are different.

I have just argued that the classical theist can avoid modal collapse only if God's act indeterministically produces its effects. I will argue in $\$ 5$ that this is actually a biconditional: the classical theist can avoid modal collapse if and only if God's act indeterministically produces its effects. This biconditional not only signals the death of modal collapse arguments (insofar as it shows that the classical theist can avert modal collapse while retaining their classical theism), but it also undergirds new problems that may accrue to classical theism (insofar as classical theists must avert modal collapse in this manner, saddled with all its accompanying costs).

But let's not get ahead of ourselves. Before establishing the biconditional, we have some other modal collapse arguments to cover.

\section{Leibniz's law}

In simplest terms, Leibniz's Law says that for every $\mathrm{x}$ and every $\mathrm{y}$, if $\mathrm{x}=\mathrm{y}$, then for any feature $\mathrm{F}, \mathrm{F}(\mathrm{x})$ if and only if $\mathrm{F}(\mathrm{y})$. This is uncontroversial-if $\mathrm{x}$ and $\mathrm{y}$ are one and the same thing, they obviously cannot differ in their properties, including their modal status. (It would be more accurate to say 'it' than 'they', but set that aside.) If they did so differ, then (e.g.) one and the same thing would be both necessary and non-necessary, which is absurd.

\footnotetext{
${ }^{10}$ Here, 'the actual creation' rigidly designates this particular creation we actually inhabit.

11 Deterministic causation occurs just in case it is impossible that the cause $\mathrm{C}$ occurs without its effect E. In other words, $<\sim$ possibly, $\mathrm{C}$ and $\sim \mathrm{E}>$. This is equivalent to: $<$ necessarily, $\sim(\mathrm{C}$ and $\sim \mathrm{E})>$, which in turn is equivalent to $<$ necessarily, if $\mathrm{C}$, then $\mathrm{E}>$. Given that God's actual act of creation is the cause of the actual creation, it follows that (5) accurately represents the relevant deterministic causal link.
} 
Leibniz's Law forms the basis of a second version of SMCA. According to DDS, God is numerically identical with his act of creation. But God exists of metaphysical necessity. But since x's being identical with y entails that $\mathrm{x}$ and $\mathrm{y}$ share the same modal status (per Leibniz's Law), it follows that God's act of creation exists of metaphysical necessity. But if God's act of creation exists of metaphysical necessity, so the argument goes, creation itself likewise exists of metaphysical necessity.

The problem with this version of the argument is that the metaphysical necessity of creation simply does not follow from the fact that God's act of creation exists of metaphysical necessity. It is true, under classical theism, that God's act of creation exists of metaphysical necessity. For the entity designated by 'God's act of creation' does, indeed, exist of metaphysical necessity. But more is needed, as Tomaszewski (2019, pp. 281-283) points out, to entail < necessarily, there exists a divine creative act $>$ than the mere fact that $<$ necessarily, there exists the entity designated by 'the divine creative act' $>$. It must also be true that 'the divine creative act' "designates that entity in every possible world. But clearly it doesn't", since in some worlds God refrains from creating and hence is not designated by the relevant definite description (ibid, p. 281).

The Leibniz's Law version of the modal collapse argument, then, doesn't work either. But Mullins (2021) responds to such criticisms with an argument that, by Mullins' lights, (i) is valid, (ii) secures the fatalistic conclusion, and (iii) is based on the core tenets of DDS. It is to this response that I turn next.

\section{Mullins' new formulation}

After providing the syllogized version of Mullins' modal collapse argument derived from Mullins (2021, pp. 94-95), I will unpack Mullins' justification for the premises. I will also critically evaluate the argument. Here is Mullins' (2021, pp. 94-95) formulation:

M1 If God intentionally acts to actualize this world, then this world cannot possibly fail to obtain.

M2 If God's intentional act to actualize this world is absolutely necessary, then this world exists of absolute necessity.

M3 God's existence is absolutely necessary.

M4 Anything that is identical to God's existence must be absolutely necessary.

M5 All of God's intentional actions are identical to each other such that there is only one divine act.

M6 God's one divine act is identical to God's existence.

$M 7$ God's one divine act is absolutely necessary. (M3-M6)

M8 God's intentional act to actualize this world is absolutely necessary. (M7)

M9 This world exists of absolute necessity. (M2, M8)

According to Mullins, (M1) expresses the infallibility of omnipotence: God's willing something to obtain strictly entails that the thing obtain; it is impossible that 
both (i) God wills that some state of affairs x obtain but (ii) x fails to obtain. God's willing something necessarily entails its obtaining. So far, so good.

Mullins then points out, rightly, that (M3) is an explicit commitment of classical theism while (M5) and (M6) are explicit commitments of DDS. Mullins also writes that "(M4) is true on pain of violating identity" (2021, p. 94). The idea here is familiar: if $\mathrm{x}$ and $\mathrm{y}$ are identical, then $\mathrm{x}$ and $\mathrm{y}$ share the same modal status. For if $\mathrm{x}$ and $\mathrm{y}$ differ in their modal status, then one and the same thing would be both necessary and non-necessary, or possible and not possible, or contingent and noncontingent. And this is absurd. Hence, if $\mathrm{x}$ and $\mathrm{y}$ are identical, then $\mathrm{x}$ and $\mathrm{y}$ share the same modal status. Hence, anything that is identical to God's existence must be absolutely necessary, given that God's existence is itself absolutely necessary. This is just Leibniz's Law.

Trouble arises, though, when we consider (M2). In particular, (M2) commits essentially the same mistake that the Leibniz's Law version of SMCA commits. (M2) states that if God's intentional act to actualize this world is absolutely necessary, then this world exists of absolute necessity. But this is a non-sequitur. All we can infer from $<$ the divine intentional act to actualize this world is absolutely necessary $>$ is that the entity designated by 'the divine intentional act to actualize this world' exists of metaphysical necessity. And this much is true, under classical theism: God is identical to God's intentional act(s), and so the entity designated by the relevant expression exists of metaphysical necessity. But more is needed to entail that $<$ necessarily, there exists the divine intentional act to actualize this world $>$ than the mere fact that $<$ necessarily, there exists the entity designated by 'the divine intentional act to actualize this world' $>$. It must also be true that 'the divine intentional act to actualize this world' designates that entity in every possible world. But upon adding this assumption to the argument, the argument becomes question-begging against the classical theist. For to say that 'the divine intentional act to actualize this world' designates God in every possible world just is to assert that necessarily, God creates this world. And yet this is precisely what was in need of demonstration.

To further drive home the point, consider the following parody $\operatorname{argument}^{12}$ :

$M 1 *<$ The infallibly omnipotent creator of this world exists $>$ necessarily entails $<$ this world exists $>$.

$M 2 *$ If the infallibly omnipotent creator of this world exists of absolute necessity, then this world exists of absolute necessity.

$M 3 *$ God exists of absolute necessity.

$M 4^{*}$ If God is identical to $\mathrm{x}$, then $\mathrm{x}$ exists of absolute necessity. (M3*, Leibniz's Law)

$M 5 *$ God is identical to the infallibly omnipotent creator of this world.

$M 6^{*}$ The infallibly omnipotent creator of this world exists of absolute necessity. (M4*, M5*)

$M 7^{*}$ This world exists of absolute necessity. (M2*, M6*)

12 This is my own parody argument, but the idea of a parody along similar lines is found in Tomaszewski (2019). 
Let's proceed through the premises. (M1*) simply follows from the infallibility of omnipotence and is clearly on epistemic par with (M1). (M3*) is simply a commitment of traditional theism ${ }^{13}$ no less than the classical theism. (M4*) follows from (M3*) and Leibniz's Law just as much as (M4) follows from (M3) and Leibniz's Law. Now, (M5*) is simply a commitment of traditional theism. God is the infallibly omnipotent creator of this world. If I asked the traditional theist to point to the individual that is the infallibly omnipotent creator of this world, the traditional theist would point to God. If God isn't the infallibly omnipotent creator of this world, then either this world is uncreated, or else the creator of the world isn't infallibly omnipotent, or else there is some other being (not God!) that is the infallibly omnipotent creator of the world. But each of these options is explicitly rejected by traditional theism. And (M6*) and (M7*) simply follow from already-canvassed premises. The only premise left is $(\mathrm{M} 2 *)$. Now, as the reader can guess, I reject (M2*) for the reasons canvassed earlier as applied to Mullins' (M2). What's important to note for present purposes is that the two are exactly parallel: both take expressions that designate a necessarily existent thing and infer, on the basis of (i) their designating necessary things and (ii) designating them in a way that entails the existence of this world, that this world exists of absolute necessity.

As I hope can be seen, then, Mullins' argument delivers the exact same fatalistic conclusion merely from the commitments of traditional theism as such-not merely classical theism, but any view on which God exists necessarily and is the infallibly omnipotent creator of this world. Thus, if classical theists face Mullins' (2021) modal collapse argument, all traditional theists do. But this is the wrong result-it indicates that we went wrong somewhere in our line of reasoning. And I aver that it is precisely $(\mathrm{M} 2 *$ ) (and, hence, (M2)) where we went wrong.

In particular, the consequent of (M2*) simply doesn't follow from its antecedent. All we can infer from < the infallibly omnipotent creator of this world exists of absolute necessity $>$ is that the entity designated by 'the infallibly omnipotent creator of this world' exists of metaphysical necessity. And this much is true, under traditional theism: God is identical to the infallibly omnipotent creator of this world, and so the entity designated by the relevant expression exists of metaphysical necessity. But more is needed to entail that $<$ necessarily, there exists the infallibly omnipotent creator of this world $>$ than the mere fact that $<$ necessarily, there exists the entity designated by 'the infallibly omnipotent creator of this world' $>$. It must also be true that 'the infallibly omnipotent creator of this world' designates that entity in every possible world. But upon adding this assumption to the argument, the argument becomes flatly question-begging against the traditional theist. For to say that 'the infallibly omnipotent creator of this world' designates God in every possible world just is to assert that necessarily, God creates this world. And yet this is precisely what was in need of demonstration in the parody argument.

\footnotetext{
13 As I use it, traditional theism is different from classical theism. Traditional theism (again, as I use it) is simply the core theistic claims common to most (if not all) models of the theistic God-God is (i) infallibly omnipotent, (ii) omniscient, (iii) perfectly good, (iv) necessarily existent, and (v) the creator of the concrete world.
} 
Mullins' new modal collapse argument, then, doesn't seem to work. Now let's move onto an underdiscussed powers-based modal collapse argument.

\section{Powers-based modal collapse argument}

Powers-based modal collapse arguments focus on God's being pure actuality, i.e., devoid of potentiality for change and for being different across worlds. This commitment of classical theism, Mullins argues, is incompatible with God's freedom. God's freedom entails that God has unactualized potential. For instance, God created this world, but he had the potential to create a different world. And this potential went unactualized. Thus, if God is purely actual-utterly devoid of potential-then God is unfree. Consequently, creation and its contents exist of metaphysical necessity, since God must create them. My aim in this section is to assess this powers-based modal collapse argument. Mullins puts the argument pithily:

Could God have refrained from creating the universe? If God is free then it seems that the answer is obviously 'yes.' He could have existed alone. Yet, God did create the universe. If there is a possible world in which God exists alone, God is not simple. He eternally has unactualized potential... (2013, pp. 195-196)

Elsewhere Mullins articulates the argument like so:

If God could create this universe, but chose not to, God would have unactualized potential. So in order to be pure act, God must create this universe. The same is true of any other potential universes that God might be able to create. Say it is possible to create a multiverse. Then God must create the multiverse. Otherwise, God will have unactualized potential and not be pure act. For any possible universe that God can create, He must create. Otherwise, God will have unactualized potential. (2016, p. 140)

To get a clearer grip on the argument, let's formalize it:

7. If God could have done $\varphi$ but does not actually do $\varphi$, then God has unactualized potential.

8. God could have created a different universe (or no universe at all), but (obviously!) did not actually do so.

9. So, God has unactualized potential. $(7,8)$

10. If God has unactualized potential, then classical theism is false.

11. So, classical theism is false. $(9,10)$

This argument, though, does not succeed—or, at the very least, it should not convince classical theists to abandon their classical theism.

Here is my first response. The classical theist will simply reject premise (7) and say that God's 'doing something different' merely amounts to a different states of affairs' obtaining (with a dependence on God). To say (without further, 
independent justification) that this requires God himself to have some unactualized potential is to beg the question against the classical theistic position, according to which God is not cross-world different despite creation being cross-world different.

Here's another way to put it. Everything on God's end is fully realized, fully actualized. God's act (with which he is identical) is fully, wholly, and purely actual. But this act can indeterministically give rise to different effects across different worlds. And we truthfully predicate 'does A (not B) in $\mathrm{w}_{\mathrm{A}}$ ' and 'does B (not A) in $\mathrm{w}_{\mathrm{B}}$ ' of God not in virtue of God's being (intrinsically or entitatively) different across such worlds, but instead in virtue of $\mathrm{A}$ indeterministically coming about in $\mathrm{w}_{\mathrm{A}}$ with a dependence on God (in the former case) and (in the latter case) B indeterministically coming about in $\mathrm{w}_{\mathrm{B}}$ with a dependence on God.

Now, one might object: wouldn't God himself be different across such worlds, inasmuch as he exercises one capacity in one world (his capacity to create A) and a different capacity in another world (his capacity to create B)?

But this is simply not the case for the classical theist. God's one, simple, immutable act (with which he is identical) exists in $\mathrm{w}_{\mathrm{A}}$ and in $\mathrm{w}_{\mathrm{B}}$; and $\mathrm{A}$ (not $\mathrm{B}$ ) indeterministically arises from God's act in $\mathrm{w}_{\mathrm{A}}$ whereas B (not A) indeterministically arises from God's act in $\mathrm{w}_{\mathrm{B}}$; and it is in virtue of these facts alone that God is said to exercise one capacity in one world and a different capacity in another world. On God's end, there is a simple, cross-world invariant act. Nevertheless, we can truthfully characterize this act differently across such worlds in virtue of the act's indeterministically producing A in one world and B in another. This view does not require God to possess any potency whatsoever, and nor does it require there to be some positive ontological item in reality which corresponds to 'a capacity to produce A' which is numerically distinct from some other positive ontological item in reality which corresponds to 'a capacity to produce B'.

But, the objector protests, how could we truthfully predicate, of God's act, that it is an act of bringing $\mathrm{A}$ (not $\mathrm{B}$ ) about in $\mathrm{w}_{\mathrm{A}}$ and an act of bringing $\mathrm{B}$ (not $\mathrm{A}$ ) about in $w_{B}$ if there isn't some corresponding difference in God? Doesn't truth correspond with reality, such that a difference in true predications requires some difference in reality itself? And so if we're truthfully predicating different (and, indeed, incompatible) things of God's act across worlds, this would surely require some difference in that act across worlds. For there is no difference in truth value without some corresponding difference in reality itself. That's just the standard correspondence theory of truth, no?

In reply, it is correct that a difference in truth across such worlds requires some difference in reality itself across such worlds. (At least by my correspondence theorist lights.) Thus, a difference in true predications concerning God's act across such worlds requires some difference in reality across such worlds. But it is a mistake to say that this requires some difference in the act itself across worlds. For we can truthfully predicate things of the act that are true not in virtue of how the act is in itself but rather how the act connects with other things. And thus the cross-world differences in true predications of God's act need not demand cross-world differences 
in the act itself but can instead — at least in principle-only demand cross-world differences in those other things to which the act is connected. ${ }^{14}$

And, so, here is the story. 'God exercises his capacity to produce A but does not exercise his capacity to produce $B$ ' is true in $\mathrm{w}_{\mathrm{A}}$ in virtue of:

12. God's act (with which God is identical);

13. A's obtaining; and

14. A's being an indeterministic effect of God's act.

By contrast, 'God exercises his capacity to produce B but does not exercise his capacity to produce $A$ ' is true in $\mathrm{w}_{\mathrm{B}}$ in virtue of:

\section{God's act (with which God is identical);}

$13 *$. B's obtaining; and

$14^{*}$. B's being an indeterministic effect of God's act.

This story doesn't require that the act itself be cross-world variant (or that there must be numerically distinct acts across worlds). Moreover, the story preserves the correspondence theory of truth, since differences in the true predications of God's act are, indeed, accompanied by differences in reality across worlds. (To see this, compare (13) and (14) with $\left(13^{*}\right)$ and $\left(14^{*}\right)$ ).

That, then, is my first response to Mullins' argument. My second response is that an exactly parallel problem would afflict non-classical theistic models of God (and, indeed, any view on which there is some indeterministic explanatory link between the necessary and the contingent). Let $\mathrm{N}$ be everything necessary (and only everything necessary) in God (e.g., God's essential attributes, the reasons and desires he essentially possesses, etc.), and let $\mathrm{C}$ be everything contingent (and only everything contingent) in God (e.g., his contingent intention(s), his contingent act of will, etc.).

Now, obviously there is going to be some explanatory link between $\mathrm{N}$ and $\mathrm{C}^{15}$ Suppose $\mathrm{C}_{1}$ (not $\mathrm{C}_{2}$ ) obtains in $\mathrm{w}_{1}$ whereas $\mathrm{C}_{2}$ (not $\mathrm{C}_{1}$ ) obtains in $\mathrm{w}_{2}$. Then, $\mathrm{N}$ could have given rise (via an indeterministic explanatory link) to $\mathrm{C}_{1}$ (and not $\mathrm{C}_{2}$ ) or $\mathrm{N}$ could have given rise to $C_{2}$ (and not $C_{1}$ ). But per the original argument's own reasoning, this would imply that in $\mathrm{w}_{1}, \mathrm{~N}$ has some potential for giving rise to $\mathrm{C}_{2}$ which goes unactualized. (And, likewise, in $\mathrm{w}_{2}, \mathrm{~N}$ has some potential for giving rise to $\mathrm{C}_{1}$ which goes unactualized.)

But this, of course, leads to a contradiction. By definition, $\mathrm{N}$ is everything necessary about God. $\mathrm{N}$ therefore has no potential for being different. To have potential

\footnotetext{
14 Alternatively, one could say that it is only those other things that are connected or related to the act (not vice versa), where the relation they bear to the act is one of causal dependence.

15 Why? Because (i) otherwise, $\mathrm{C}$ is just an inexplicable, brute happening; (ii) God contingently acts as he does at least in part because of who he is (e.g., because he is loving, merciful, just, etc.), and this means that $\mathrm{C}$ is explained at least in part by $\mathrm{N}$; and (iii) God's contingent acts are not arbitrary but instead are reason-based, and this means that his acts are partially explained in terms of the reasons which God essentially has (e.g. in every possible world, God has (non-necessitating) reason to actualize moral agents with whom he can share his love).
} 
for being different would imply some contingency (even if only a contingent property). But that's absurd, since $\mathrm{N}$ is by definition wholly necessary, with no admixture of contingency.

The parody argument, then, would run:

$7^{*}$. If $\mathrm{N}$ could have given rise to $\varphi$ but does not actually give rise to $\varphi$, then $\mathrm{N}$ has unactualized potential.

8*. $\mathrm{N}$ could have given arise to different contingent features of God (e.g., the contingent act of refraining to create the universe), but (obviously!) did not actually do so.

9*. So, $\mathrm{N}$ has unactualized potential. $\left(7^{*}, 8^{*}\right)$

$10^{*}$. If $\mathrm{N}$ has unactualized potential, then non-classical theism is false. ${ }^{16}$

$11^{*}$. So, non-classical theism is false. $\left(9^{*}, 10^{*}\right)$

Perhaps there's some symmetry breaker in terms of the link between the classical theistic God and creation being causal as opposed to the link between $\mathrm{N}$ and $\mathrm{C}$ being non-causal. But, first, it's hard to see why this constitutes a relevant difference. (After all, surely what matters here is simply the indeterminism, which is present on both accounts). And, second, the onus of justification is on the proponent of the powers-based modal collapse argument to show why this is a symmetry breaker (not on the detractors to show why it $i s n ' t$ ) - and that's something proponents of such arguments have yet to do.

For these two reasons, the powers-based modal collapse argument does not succeed.

\section{The death of modal collapse arguments}

Reflection on the aforementioned argument provides us with a tool for seeing why any modal collapse argument based solely on (i) the identity of God with God's act of creation or (ii) God's being purely actual will not succeed. All that's needed is indeterministic causation - that is, causation in which the existence of the cause, C, does not necessitate the existence of the effect, E. So long as God's act (with which he is identical) merely indeterministically causes its effects, modal collapse is entirely averted. For in indeterministic causation, one and the same $\mathrm{C}$ exists in worlds in which $\mathrm{E}$ exists and in worlds in which $\mathrm{E}$ does not exist. $\mathrm{C}$ is thus not cross-world variant-given identical causal conditions C, E may or may not obtain. No potential feature of the cause is actual in one world that isn't actual in the other, in this case, since identical causal conditions $\mathrm{C}$ obtain in each world. Moreover, $\mathrm{C}$ can be metaphysically necessary without $\mathrm{E}$ being metaphysically necessary, since

\footnotetext{
${ }^{16}$ Since non-classical theism requires that $\mathrm{N}$ is wholly necessary-in which case, it is devoid of contingency. And in that case, it is also devoid of potency. (I am assuming that the non-classical theist agrees with the classical theist that God is not a contingent being).
} 
$\mathrm{C}$ exists in worlds without $\mathrm{E}$ (by dint of the causal link between $\mathrm{C}$ and $\mathrm{E}$ being an indeterministic one).

Applying this to the classical theistic God, we can see that so long as the causal link between God (else: God's act, with which God is identical) and creation is indeterministic, then God need not have some potency which is actualized in one world instead of another; and, moreover, the effect need not be metaphysically necessary simply by dint of the cause's being metaphysically necessary. God can be both metaphysically necessary and utterly devoid of potency whilst creation itself is wholly contingent. This much simply follows from the notion of indeterministic causation. To mount modal collapse arguments, then, detractors of classical theism must add a premise to the effect that indeterministic causation is impossible, or at least indeterministic causation between God (as cause) and creation (as effect) is impossible. And not only must they add such a premise; they must justify it (lest they beg the question against the classical theist).

But such a justification might well do more harm than good. For, plausibly, it will equally rule out any libertarian view of free will. Moreover, any argument for the impossibility of indeterministic causation would seem equally to support the impossibility of any kind of indeterministic dependence. But in that case, non-classical theists are equally threatened, since God's contingent act of creation, under nonclassical theistic models of God, is dependent on more fundamental, necessary features of God (e.g., God's character, knowledge, perfection, goodness, desires, reasons, etc.). And in that case, non-classical theists are committed to indeterministic dependence no less than classical theists.

Finally, note that God's being identical with his act does nothing, by itself, to entail modal collapse if the link between that act and its effect (viz., creation) is indeterministic. In worlds in which the act gives rise to a creation, one can truly predicate, of that act, that it is a divine creative act and that the act (by dint of being identical to God) is absolutely necessary. In worlds in which that self-same act gives rise to no creation, one can truly predicate, of that act, that it is a divine refraining-from-creating act and that the act is absolutely necessary. ${ }^{17}$ To drive this point home, consider again non-classical theism's commitment to God's necessary layer/ features $\mathrm{N}$ and contingent layer/features $\mathrm{C}_{1}$ and $\mathrm{C}_{2}$ (where $\mathrm{C}_{1}$ is all and only God's contingent features in one world and $\mathrm{C}_{2}$ is all and only God's contingent features in a different world, and where $\mathrm{C}_{1}$ is different from $\mathrm{C}_{2}$ ). We can now say: in worlds in which $\mathrm{N}$ gives rise to $\mathrm{C}_{1}$, one can truly predicate, of $\mathrm{N}$, that it is a $\mathrm{C}_{1}$-generating thing and that this thing (i.e., the entity picked out by 'the $\mathrm{C}_{1}$-generating thing') is absolutely necessary. In worlds in which that self-same $\mathrm{N}$ gives rise to $\mathrm{C}_{2}$ instead, one can truly predicate, of $\mathrm{N}$, that it is a $\mathrm{C}_{2}$-generating thing and that this thing is absolutely necessary. The cases of non-classical and classical theism are exactly parallel. Moreover, the facts that (i) $\mathrm{N}$ is a $\mathrm{C}_{1}$-generating thing in one world and that (ii) $\mathrm{N}$ is absolutely necessary plainly do not entail that (iii) necessarily, there is a

\footnotetext{
17 All that's needed is that the relevant predication is true not in virtue of how God is in himself but instead in virtue of creation's dependence (or lack thereof) on God. In other words, all we need is that the relevant predication is extrinsic.
} 
$\mathrm{C}_{1}$-generating thing. Likewise, the facts that (i) God is a divine creative act in one world and that (ii) God is absolutely necessary plainly do not entail that (iii) necessarily, there is a divine creative act. ${ }^{18}$

The upshot, I think, is this. We've here established the right-to-left side of the biconditional from earlier: the classical theist can avoid modal collapse if and only if God's act indeterministically produces its effects. So long as indeterminism is an option for the classical theist-which, it should be noted, must be an option for any theist (classical or non-classical) who thinks God is free to create or refrain from creating - the modal collapse objections based on God's pure actuality or God's identity with God's acts are—to put things polemically—dead. But the death is not fruitless. For it paves the way for new potential problems for classical theism. It is to a brief sketch of these problems that I turn next.

\section{A fruitful death}

The death of modal collapse arguments is not something to mourn. For reflection on such arguments spawn new paths of inquiry that can and should be explored in future work. My purpose in this section is not to defend the following paths; it is, instead, to motivate and sketch them in the hopes of advancing modal collapse debates beyond death and into fruits.

\section{Intentional directedness}

The first problem derives from what, upon reflection, seems to be essential to intentional action. An intentional action seems, of its very nature, directed towards the specific, definite outcome the agent seeks to actualize. Consider: plausibly, an intentional causal act is ultimately goal-oriented; it is directed towards (aimed at, about, targets) a distinct state of affairs. This just seems constitutive of intentional actionsuch actions are, by their very natures, directed toward or referred to a distinct target state.

But—and this is where the problem comes in—it seems that classical theists must deny this intuitively plausible understanding of the nature of intentional action. For God's act of creation is certainly an intentional act (if only analogously so). That God is personal and hence intentionally acts is a core commitment of traditional theism, and so a fortiori it is likewise a core commitment of classical theism. ${ }^{19}$

\footnotetext{
${ }^{18}$ It should be clear, from context, that in each of the previous two sentences, (iii) is intended to be read de dicto rather than de re. That is, the first instance of (iii) means: the necessary truth of the proposition $<$ there is a $\mathrm{C}_{1}$-generating thing $>$, while the second instance of (iii) means: the necessary truth of the proposition $<$ there is a divine creative act $>$.

${ }^{19}$ Could the classical theist deny that God intentionally acts? It's hard to see how. First, this runs contrary to the explicit affirmations of at least many classical theist scholars. As Thomas Ward points out, at least for Christian classical theistic reflection on the doctrine of creation, God's intentional action must serve as a guidepost and foundation (Ward, 2020, p. 5). And as the classical theist Ron Highfield explains, "God's act of creating is not irrational or arbitrary but is accompanied by God's intentions and is directed toward an end" (Highfield, 2015, p. 77). Second, part of what demarcates theism from views
} 
But God's (creative) intentional act(s), under classical theism, cannot be directed towards a specific, determinate outcome. This is because under classical theism, God's one, simple act (across all possible worlds) is numerically identical to God himself. Whether God's simple act brings about an infinite multiverse, or infinitely many infinite multiverses, or a finite universe, or nothing at all—or anything in between-absolutely nothing about God himself and his states (e.g., intentions, desires, willings, etc.) varies. There is thus absolutely nothing about God's act itself which makes it an intentional act to bring about this particular universe (as opposed to that other one, or none at all). Nothing about the act itself is directed towards any one specific creation in particular, since one and the same act-without any crossworld variance or difference-would have counted as an intentional act to actualize creation $\mathrm{C}$ (for any possible creation $C$, or even the utter absence of created things) no matter which C obtained. The act itself is therefore not directed toward or referred to any outcome in particular among the infinite array of possible outcomes. (In fact, this seems straightforwardly entailed by the responses on behalf of classical theism, presented and defended earlier, in response to modal collapse arguments. For such responses grant that God's act is only an intentional act to create in virtue of creation itself obtaining. Nothing about the act itself, then, specifies whether it is an intentional act to create. Its status as such is parasitic on the effect itself coming to be). And as we've seen, this result contradicts what prima facie seems to be the very nature of intentional action.

Now, one might, along lines similar to those pursued in Grant and Spencer (2015), respond to the abovementioned problem by saying that whether or not God's intentional acts are directed towards a specific, target outcome depends on how we 'divvy up' (as it were) said acts (i.e., on what we take such acts to consist in). In particular, we must distinguish between what is involved in such acts on God's side from what such acts consist in taken as a whole (i.e., the entire ontological foundation for our predications of actions intending creatures to God) (ibid). For although nothing on God's side is directed to any specific effect, the action as a whole may be directed towards a specific effect in virtue of partly consisting in that very effect. So- the objection continues - depending on how we divvy up God's acts, the classical theist can preserve the deeply intuitive understanding of the nature of intentional acts as by nature directed towards a specific target state.

This is a valuable objection. Here's a reply on behalf of the original problem. ${ }^{20}$ Even if this objection preserves directedness toward a specific outcome for the act

\footnotetext{
Footnote 19 (continued)

like deism and various non-theisms is that ultimate reality is personal (in some sense-perhaps only analogously). And surely acts intentionally is partly constitutive of being personal. Third, some of the most powerful arguments for theism not only become unavailable to classical theists if they deny that God intentionally acts, but they also become arguments against classical theism. For instance, the finetuning argument, all sorts of teleological arguments, and many more arguments besides—if successful— show that whatever is ultimately responsible for the universe is antentional agent.

${ }^{20}$ Recall that I am not mounting these problems as positive arguments against classical theism; I am simply sketching such problems in the hopes of advancing modal collapse debates to issues about divine action raised by the death of modal collapse arguments.
} 
as a whole, it doesn't seem to preserve it for the entity of which such preservation is needed in order to respect the intuitive idea that intentional acts are by nature directed towards a specific target state. The driving force behind the intuition is that something about the agent themself-some 'doing' of theirs, some activity on their end, not on the part of their effects-is by nature directed toward the specific effect in question. It is by dint of this that the agent can be meaningfully said to intentionally act - or so the intuitive thought goes. To say that the essential directedness toward a distinct target state simply consists in that target state itself coming about seems to quite literally change the subject-to change what is intuitively required to be the subject of the 'essential directedness toward'-namely, the agent themself, or something about them-to some other subject-namely, the effect itself coming to be. Indeed, the coming-to-be of the effect itself is intuitively posterior to and resultant from the intentional directedness of the agent's act and hence cannot be that in virtue of which the act is intentionally directed in the relevant manner. Thus, the original problem retains its force.

Here's another objection. God's intention is directed toward one distinct state of affairs that is love of himself. The created effects fall under this broader intention and are therefore effects of one and the same act with the same intention across all possible worlds.

By way of response, this objection just doesn't seem to target the problem. The problem is as follows. God intentionally acts (if only analogously so) to create this particular world. Intentional acts are by nature directed towards their intentional object(s), i.e., that toward which they aim. In other words, God's intentional act to create this particular world is by nature directed towards this particular world. But under DDS, on which God is identical to his one act across all possible worlds, none of God's intentional acts are by nature directed towards any particular world. So, DDS is false. Pointing to the fact that God's act isn't, after all, directed toward this particular world but instead directed to loving himself is only to reinforce the argument: it is simply to grant that God's acts across worlds aren't, after all, intentionally directed specifically toward the relevant created effects in that world. Instead, the intention is exactly as it is in any other world, including ones in which an infinite multiverse co-obtains with God to ones in which God exists alone to everything in between. Far from undermining the problem, then, this objection arguably supports it.

\section{Providence}

Let's consider, now, the second new potential problem for classical theism resulting from the death of modal collapse arguments. In particular, the problem is that classical theism seems to exacerbate the problem of luck for libertarianism and thereby threatens God's radical providence over which precise creation obtains (and, indeed, whether creation obtains at all). ${ }^{21}$ For under classical theism, one can fix all the facts

\footnotetext{
${ }^{21}$ For some treatments of the problem of present luck for libertarianism (which is a version of the luck objection), see (inter alia) Haji (2003), ( 2013), Levy (2005), Mele (2006), Franklin (2011), and Shabo (2014).
} 
about God himself and yet any creation whatsoever (or no creation at all) among the infinite array of possible creations can spring into being with a dependence on God. This simply follows from the radical indeterministic causal link between God and God's effect needed to avoid modal collapse arguments. Every fact solely about God is perfectly compatible with any creation whatsoever coming into being; there is no distinctive intentional act to bring about this particular creation. At the very least, this intuitively calls into question how God could be in control of whether this particular creation comes into being. Had any other of the infinite creations come about, nothing about God would have differed. And in that case, there is nothing we can cite on God's end to explain why this particular creation came into being. And in that case, it's hard to see how God can providentially control whether this particular creation (as opposed to the infinitely many others, or no creation at all) comes about.

To be sure, the literature on the luck objection is vast, and if it's a problem for classical theism, it is likely a problem for non-classical theisms too concerning the indeterministic link between God's necessary features $\mathrm{N}$ and God's contingent features C. But-and this is where a 'distinctive' problem for classical theism may arise-non-classical theisms seem to have resources for mitigating the problem that are unavailable to classical theism. In particular, many defenders of libertarianism hold that the possession of a variety of reasons upon which one's choices across worlds are differentially dependent can help mitigate the luck objection, since one's actions-though not necessitated by the reasons in question-are still undergirded by reasons that distinctively favor each action in the respective worlds in which such actions obtain. One example of this response to luck objections is in Franklin (2012), who holds that something only counts as an agential action if it is appropriately caused by the agent's relevant mental states like "beliefs, desires, reasons, and intentions" (396-397). And even if one has reservations about a causal link between such prior mental states and the agent's act (say, because one thinks it is incompatible with agent-causal libertarian theories), few will deny the plausibility of there being some kind of dependence relation here (even if non-causal).

In keeping with this response, non-classical theisms can hold that there exists a multiplicity of reasons upon which God's different intentional acts across worlds are dependent, such that different reasons factor differentially into the explanation of God's choices across worlds. But the existence of such a multiplicity of reasons would plausibly entail that there are positive ontological items intrinsic to but numerically distinct from God, meaning that classical theists cannot avail themselves of this maneuver. Moreover, the proposal in question entails that God's acts are dependent things - they are dependent on prior reasons. But God, under classical theism, is identical to God's acts, and hence if God's acts depend on something prior, God himself depends on something prior (thus violating divine aseity).

Once more, I emphasize that I am not here defending either of the above two problems. Instead, I am sketching and motivating them in hopes that the modal collapse literature shifts its focus on new problems - new fruits-arising from the death of modal collapse arguments. 


\section{Conclusion}

I first articulated the SMCA in two variants and characterized and defended Tomaszewski's (2019) criticism thereof. I then critically examined Mullins' (2021) new modal collapse argument as well as a powers-based modal collapse argument. I next argued that modal collapse arguments based solely on God's pure actuality or God's identity with God's act(s) cannot succeed so long as we grant indeterministic causation. I then drew out two fruits of the death of modal collapse arguments that will, I hope, serve to advance discussions about divine action, God's nature, and modal collapse. ${ }^{22}$

Funding No funding.

\section{Declaration}

Conflict of interest The authors declare that they have no conflict of interest.

\section{References}

Anselm. (2001). Proslogion: With the replies of Gaunilo and Anselm. Hackett publishing company. Translated by $\mathrm{T}$. Williams.

Augustine. (1887). The City of God. In P. Schaff (Ed.), Nicene and Post-Nicene Fathers, First Series (Vol. 2). Translated by Marcus Dods. Buffalo, NY: Christian Literature Publishing Co. Revised and edited for New Advent by Kevin Knight. Retrieved from https://www.newadvent.org/fathers/1201.htm.

Bergmann, M., \& Brower, J. E. (2006). A theistic argument against platonism (and in support of truthmakers and divine simplicity). In D. W. Zimmerman (Ed.), Oxford studies in metaphysics. Oxford: Oxford University Press.

Brower, J. E. (2009). Simplicity and aseity. In T. P. Flint \& M. C. Rea (Eds.), The oxford handbook of philosophical theology. Oxford: Oxford University Press.

Dolezal, J. E. (2011). God without parts: Divine simplicity and the metaphysics of god's absoluteness. Pickwick Publications.

Dolezal, J. E. (2017). All that is in god: Evangelical theology and the challenge of classical christian theism. Reformation Heritage Books.

Duby, S. J. (2016). Divine simplicity: A dogmatic account. Bloomsbury.

Fakhri, O. (2021). Another look at the modal collapse argument. European Journal for Philosophy of Religion., 13(1), 1-23.

Franklin, C. E. (2011). Farewell to the luck (and mind) argument. Philosophical Studies, 156, 199-230.

Franklin, C. E. (2012). The assimilation argument and the rollback argument. Pacific Philosophical Quarterly, 93, 395-416.

Grant, W. M. (2012). Divine simplicity, contingent truths, and extrinsic models of divine knowing. Faith and Philosophy, 29, 254-274.

Grant, W. M. (2019). Free will and god's universal causality: The dual sources account. Bloomsbury Academic.

Grant, W. M., \& Spencer, M. K. (2015). Activity, identity, and god: A tension in aquinas and his interpreters. Studia Neoaristotelica, 12, 5-61.

Haji, I. (2003). Alternative possibilities, luck, and moral responsibility. The Journal of Ethics, 7(3), $253-275$

$\overline{22}$ Thanks to an anonymous referee for helpful comments. 
Haji, I. (2013). Event-causal libertarianism's control conundrums. Grazer Philosophische Studien, 88, 227-246.

Highfield, R. (2015). The faithful creator: Affirming creation and providence in an age of anxiety. InterVarsity Press.

Hughes, C. (2018). Aquinas on the nature and implications of divine simplicity. European Journal for Philosophy of Religion, 10, 1-22.

Kaplan, D. (1979). On the logic of demonstratives. Journal of Philosophical Logic, 8, 81-98.

Leftow, B. (2015). Divine simplicity and divine freedom. Proceedings of the American Catholic Philosophical Association, 89, 45-56.

Levy, N. (2005). Contrastive explanations: A dilemma for libertarians. Dialectica, 59(1), 51-61.

Lewis, D. K. (1986). On the plurality of worlds. Blackwell Publishing.

Marshall, D., \& Weatherson, B. (2018). Intrinsic vs. extrinsic properties. Stanford encyclopedia of philosophy. Retrieved from https://plato.stanford.edu/entries/intrinsic-extrinsic/.

Mele, A. (2006). Free will and luck. Oxford University Press.

Moreland, J. P., \& Craig, W. L. (2003). Philosophical foundations for the christian worldview. InterVarsity Press.

Mullins, R. T. (2013). Simply impossible: A case against divine simplicity. Journal of Reformed Philosophy, 7, 181-203.

Mullins, R. T. (2016). The end of the timeless god. Oxford University Press.

Mullins, R. T. (2021). Classical theism. In J. M. Arcadi \& J. T. Turner (Eds.), T\&T clark handbook of analytic theology. New York: T\&T Clark.

Nemes, S. (2020). Divine simplicity does not entail modal collapse. In C. F. C. da Silveira \& A. Tat (Eds.), Roses and Reasons: Philosophical Essays. Eikon.

Rogers, K. A. (1996). The traditional doctrine of divine simplicity. Religious Studies, 32(2), 165-186.

Schmid, J. C., \& Mullins, R. T. (2021). The aloneness argument against classical theism. Religious Studies. https://doi.org/10.1017/S0034412520000554.

Shabo, S. (2014). Assimilations and rollbacks: Two arguments against libertarianism defended. Philosophia, 42, 151-172.

Sijuwade, J. R. (2021). Divine simplicity: The aspectival account. European Journal for Philosophy of Religion. https://doi.org/10.24204/ejpr.2021.3306

Spencer, M. K. (2017). The flexibility of divine simplicity: Aquinas, scotus, palamas. International Philosophical Quarterly, 57(2), 123-139.

Stump, E. (2013). The nature of a simple god. Proceedings of the ACPA, 87, 33-42.

Tomaszewski, C. (2019). Collapsing the modal collapse argument: On an invalid argument against divine simplicity. Analysis, 79(2), 275-284.

Vallicella, W. F. (2019). Divine simplicity. Stanford encyclopedia of philosophy. Retrieved from https:// plato.stanford.edu/entries/divine-simplicity/.

Waldrop, J. W. (Forthcoming). Modal collapse and modal fallacies: No easy defense of simplicity. American Philosophical Quarterly.

Ward, T. M. (2020). Divine ideas. Cambridge University Press.

Publisher's Note Springer Nature remains neutral with regard to jurisdictional claims in published maps and institutional affiliations. 